\title{
Is hysterolaparoscopy a real theranostic approach for anatomical barriers in female fertility? A future argument
}

\author{
Namita Agrawal*, Poonam Yadav, S. Fayyaz, Brinderjeet Kaur
}

Department of Obstetrics and Gynecology, Santokba Durlabhji Memorial Hospital and Research Centre (SDMH), Jaipur Rajasthan, India

Received: 09 April 2018

Accepted: 02 May 2018

\section{*Correspondence:}

Dr. Namita Agrawal,

E-mail: namitaagarwalsms@gmail.com

Copyright: () the author(s), publisher and licensee Medip Academy. This is an open-access article distributed under the terms of the Creative Commons Attribution Non-Commercial License, which permits unrestricted non-commercial use, distribution, and reproduction in any medium, provided the original work is properly cited.

\section{ABSTRACT}

Background: Hysterolaparoscopy is a modality that provides the real time abdomino-pelvic view during diagnosis in infertile female patients and any pathology is noticed can be tackled at the same time. So we investigate the theranostic application of hysterolaparoscopy in structural causes of female infertility in present study.

Methods: Authors prospectively evaluate 157 female patients (mean age 27.7 years) diagnosed as infertile, underwent hysterolaparoscopy during diagnostic work-up. All the enlisted patients fulfilled the criteria of infertility. The noticed anatomical abnormalities in the hysterolaparoscopy were tackled at the same time if possible.

Results: Of the 157 infertile female patients, $93(\sim 59.2 \%)$ were of primary infertility and remaining $64(\sim 41.8 \%)$ were secondary infertility patients. Hysterolaparoscopy showed abnormalities in 125/157 ( 85.0\%) patients. The detected hysterolaparoscopic abnormalities were distributed in 77/93 ( 82.8\%) primary and 48/64 ( 75.0\%) secondary infertility patients. Of the 125 patients with abnormal hysterolaparoscopic findings, 121 ( $96.8 \%)$ experienced for active therapeutic interventions. All of the 48 secondary infertility patients with hysterolaparoscopic abnormalities experienced for active hysterolaparoscopic interventions. Of 77 patients with hysterolaparoscopic abnormality in primary infertility group, $73(\sim 94.8 \%)$ experienced active intervention. Only four patients with streak ovaries and hypoplastic uterus, few tiny fibroids and adenomyosis did not undergo for active hysterolaparoscopic intervention.

Conclusions: Authors concluded that hysterolaparoscopy has a better theranostic approach for the anatomical barriers of female fertility so it can be performed in the initial phases of the infertility diagnostic work-up.

Keywords: Anatomical barriers, Female fertility, Hysterolaparoscopy, Theranostic

\section{INTRODUCTION}

The future of medicine is found in the personalised medicine' (PM), that's aim is to deliver the right treatment at the right time to the right patient. ${ }^{1,2}$ So the concept of "theranostics" was coined to define ongoing efforts in clinics to develop more specific, individualized therapies for various diseases, and to combine diagnostic and therapeutic capabilities into a single agent/modality. ${ }^{3}$ The rationale of the theranostic arises from the fact that diseases are immensely heterogeneous and existing treatments are effective only for limited patient subpopulations. Theranostics cover a wide range of topics, which includes predictive medicine, personalized medicine, integrated medicine, and pharmacodiagnostics. ${ }^{3-5}$ The fertility is classified in various ways and it can be classified on anatomical and functional basis. For female infertile patient's, various abdomino-pelvic anatomical causes are responsible for infertility. The common anatomical causes of female infertility are ovarian cyst/ tumor (lead to ovulation dysfunction), tubal damage, endometriosis, and 
congenital (septate uterus) /acquired (myomas and synechiae) uterine anomalies. ${ }^{6}$ In the anatomical causes, surgical intervention plays a significant role to improve the fertility outcome. ${ }^{6}$ Most of abdomino-pelvic pathologies are required specific treatments to the individualized pathologies. The endoscopic methods such as, laparoscopy and hysteroscopy are commonly used in an evaluation of infertility and pelvic pain. Laparoscopy is a method of direct visualization of abdomen, pelvis and pelvic genital organs (ovaries, fallopian tubes, and uterus). Another endoscopic method, hysteroscopy is used for direct visualization of uterine cavity and bilateral ostea. It also makes identification and correct localization of the possible intrauterine pathologies reasonably easier. These endoscopic methods have capabilities to diagnose and to tackle the abdominopelvic pathologies simultaneously at the same sitting. ${ }^{7-10}$ So authors want to investigate its theranostic application and effectiveness in infertile woman.

\section{METHODS}

The present study was prospective analytic study and carried out between March 2016 to May 2017 at the Department of Obstetrics and Gynaecology at Santokba Durlabhji Memorial Hospital, Jaipur (Tertiary Care Centre).

\section{Inclusion criteria}

- Infertile female patients with age 19-35years.

- Regular and irregular menstrual cycle,

- Couple, who did not conceive even after at least oneyear of unprotected regular sexual intercourse

- Normal partner seminogram

- Investigations

- Hemoglobin, complete blood count (CBC), Erythrocyte sedimentation rate (ESR), Random blood sugar, thyroid function test- within normal limit

- Ovulatory function, husband semen analysis, hormonal profile (TSH/FSH/LH/Prolactin) and APLA (anti phosphor lipid antibody) levels (if available and only in secondary infertility)- within normal limit.

\section{Exclusion criteria}

- $\quad$ Age <19year; >35 year

- Abnormal husband Semen analysis

- Abnormal Hormonal profile

- Active genitourinary infection

- Any treatment, chronic illness and MPA (Medroxy progesterone acetate) contraception that imparts a negative effect on fertility.

Infertile female patients, age between 19-35 years were registered to participate in the study after taking the informed and written consent. After detailed history (together as well as separately) and clinical examination (general, systemic and gynecological examination), routine investigations were performed. Pelvic ultrasonography findings were recorded in all enlisted patients. After considering the exclusion criteria and contraindications of the operative procedure, hysteroscopy and laparoscopy were concurrently performed at SDMH, Jaipur, Rajasthan. The uterus, anterior and posterior cul-de-sacs, fallopian tubes, ovaries, ovarian fossae, pelvic peritoneum, appendix and liver surface were examined during the procedure, if some abnormalities were seen and it was noted down as shown in Table 1 and 2. Chromopertubation (CPT) was performed in all cases.

Table 1: Categorization of findings of laparoscopy in infertility patients.

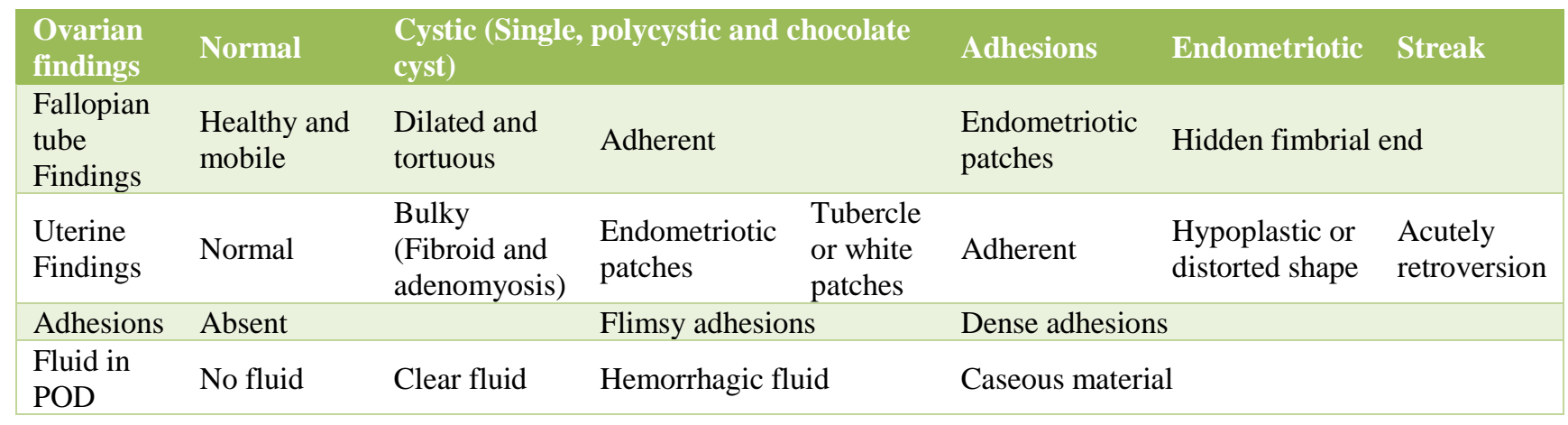

Therapeutic interventions were performed at the same sitting, if required. These included ovarian drilling, adhesiolysis, ablation of endometriotic spots, cystectomy, synechiolysis, septum resection, polypectomy and cannulation. After offering the successful treatment, Patient's were advised for regular sexual activity. 
Approval of the institutional ethical committee was obtained for this prospective study. In view of the prospective study design, written informed consent was obtained.

Table 2: Categorization of findings of hysteroscopy and CPT (Chromopertubation) in infertility patients.

\begin{tabular}{|c|c|c|c|c|c|c|}
\hline \multicolumn{7}{|l|}{ Hysteroscopic findings } \\
\hline Uterine cavity & Normal & $\begin{array}{l}\text { Small } \\
\text { size }\end{array}$ & $\begin{array}{l}\text { Hypertrophied } \\
\text { endometrium }\end{array}$ & $\begin{array}{l}\text { Septum } \\
\text { (Complete or } \\
\text { incomplete) }\end{array}$ & $\begin{array}{l}\text { Polyp or } \\
\text { fibroid }\end{array}$ & $\begin{array}{l}\text { Tubercle or } \\
\text { white } \\
\text { patches }\end{array}$ \\
\hline Both osteal end & \multicolumn{2}{|l|}{ Well visualized } & \multicolumn{2}{|l|}{ Not visualized } & \multicolumn{2}{|c|}{ Osteal webbing } \\
\hline Cervix & \multicolumn{2}{|l|}{ Normal } & \multicolumn{4}{|l|}{ Stenosis } \\
\hline External os and internal os & \multicolumn{2}{|l|}{ Normal } & \multicolumn{4}{|l|}{ Abnormal } \\
\hline \multicolumn{7}{|l|}{ CPT findings } \\
\hline $\begin{array}{l}\text { CPT findings of fallopian } \\
\text { tubes }\end{array}$ & $\begin{array}{l}\text { Bilateral } \\
\text { spill present }\end{array}$ & \multicolumn{3}{|c|}{ Unilateral blockage } & \multicolumn{2}{|c|}{ Bilateral blockage } \\
\hline
\end{tabular}

\section{Statistical analysis}

All enlisted patients were divided into two subgroups, primary and secondary infertility and the detected pathologies and treatment in each group during the hystero-laparoscopic procedure were noted. The analysis between the two groups and continuous variables were summarized as mean and standard deviation, whereas nominal/categorical variables were summarized as proportions. Parametric tests [Student t test] were used for analysis of continuous variables while Chi-square was used for nominal/ categorical variables. ' $p$ ' value $<0.05$ was considered as significant. IBM-SPSS version 22.0 software was used for all statistical analysis.

\section{RESULTS}

157 female patients with the complained of infertility were included in the present study. The mean age of patients was 27.7 years (range of 19-35years).

All enlisted patients fulfilled the inclusion criteria of the present study. On the basis of obstetric history, patients were divided in primary and secondary infertility. The characteristics of all patients are given in Table 3.

After the detail history, clinical examination and biochemical evaluation, all patients underwent the pelvic ultrasound. The abnormities detected in the USG of primary and secondary infertile patients were noted down.

\section{Hysterolaparoscopic findings (diagnostic)}

After the initial evaluation, all patients underwent hysterolaparoscopy. Out of 157 patients, abnormalities were detected in $125 / 157 \quad(79.6 \%)$ patients during Hysterolaparoscopy and underwent various therapeutic interventions according to the detected abnormalities.
Independently the abnormalities detected in the primary and secondary infertile are tabulated in Table 2 and 3.

Table 3: Characteristics of infertility patients (Age, BMI).

\begin{tabular}{|c|c|c|}
\hline \multicolumn{2}{|c|}{ Infertility (Total number of patients) 1} & 157 \\
\hline \multirow{2}{*}{$\begin{array}{l}\text { Age } \\
\text { (In years) }\end{array}$} & $\begin{array}{l}\text { Mean } \pm \text { standard } \\
\text { deviation }\end{array}$ & $27.72 \pm 3.82$ \\
\hline & Range & $19-35$ \\
\hline \multirow{2}{*}{$\begin{array}{l}\mathrm{BMI} \\
\left(\mathrm{Kg} / \mathrm{M}^{2}\right)\end{array}$} & $\begin{array}{l}\text { Mean } \pm \text { standard } \\
\text { deviation }\end{array}$ & $21.80 \pm 3.03$ \\
\hline & Range & $15.6-33.3$ \\
\hline \multicolumn{2}{|c|}{$\begin{array}{l}\text { Primary infertility (Number of } \\
\text { patients) }\end{array}$} & $\begin{array}{l}93 / 157 \\
(59.2 \%)\end{array}$ \\
\hline \multirow{2}{*}{$\begin{array}{l}\text { Age } \\
\text { (In years) }\end{array}$} & $\begin{array}{l}\text { Mean } \pm \text { standard } \\
\text { deviation }\end{array}$ & $26.59 \pm 3.23$ \\
\hline & Range & $19-34$ \\
\hline \multirow{2}{*}{$\begin{array}{l}\mathrm{BMI} \\
\left(\mathrm{Kg} / \mathrm{M}^{2}\right)\end{array}$} & $\begin{array}{l}\text { Mean } \pm \text { standard } \\
\text { deviation }\end{array}$ & $21.84 \pm 3.30$ \\
\hline & Range & $16-33.3$ \\
\hline \multicolumn{2}{|c|}{$\begin{array}{l}\text { Secondary infertility (Number of } \\
\text { patients) }\end{array}$} & $64 / 157$ \\
\hline \multirow{2}{*}{$\begin{array}{l}\text { Age } \\
\text { (In years) }\end{array}$} & $\begin{array}{l}\text { Mean } \pm \text { standard } \\
\text { deviation }\end{array}$ & $29.35 \pm 4.04$ \\
\hline & Range & $20-35$ \\
\hline \multirow{2}{*}{$\begin{array}{l}\text { BMI } \\
\left(\mathrm{Kg} / \mathrm{M}^{2}\right)\end{array}$} & $\begin{array}{l}\text { Mean } \pm \text { standard } \\
\text { deviation }\end{array}$ & $21.7 \pm 2.62$ \\
\hline & Range & $15.6-28.8$ \\
\hline
\end{tabular}

There was no statistically significant difference between primary and secondary infertile patients for the laproscopic abnormalities (p 0.404).

While, the hysteroscopic abnormalities in primary infertile patients were significantly higher $(\mathrm{p}<0.05)$ from the secondary infertile patients. These abnormal findings in the laparoscopy and hysteroscopy are summarized in Table 4 and 5 respectively. 
Table 4: Summary of the abnormalities detected in the laparoscopic examination in primary and secondary infertility patients.

\begin{tabular}{|c|c|c|c|c|c|}
\hline $\begin{array}{l}\text { Laparoscopic } \\
\text { organ } \\
\text { abnormality }\end{array}$ & $\begin{array}{l}\text { Primary } \\
\text { infertility }\end{array}$ & $\begin{array}{l}\text { Secondary } \\
\text { infertility }\end{array}$ & $\begin{array}{l}\text { Sub-categorization of } \\
\text { abnormalities }\end{array}$ & $\begin{array}{l}\text { Primary } \\
\text { infertility }\end{array}$ & $\begin{array}{l}\text { Secondary } \\
\text { infertility }\end{array}$ \\
\hline \multirow{4}{*}{$\begin{array}{l}\text { Ovarian } \\
\text { abnormalities }\end{array}$} & \multirow{4}{*}{$\begin{array}{l}54 / 93 \\
(58.4 \%)\end{array}$} & \multirow{4}{*}{$24 / 64(37.5 \%)$} & $\begin{array}{l}\text { Cystic abnormality } \\
\text { (Polycystic, } \\
\text { single cystic) }\end{array}$ & $\begin{array}{l}\text { 38/54(70.4\%) } \\
\text { (Polycystic - } \\
\text { 34Single cyst-4) }\end{array}$ & $\begin{array}{l}\text { 18/24 (75\%) } \\
\text { (Polycystic - } \\
\text { 13Single cyst-5) }\end{array}$ \\
\hline & & & Adherent & 9 & 5 \\
\hline & & & Endometriotic & 6 & 1 \\
\hline & & & Streak & 1 & 0 \\
\hline \multirow{4}{*}{$\begin{array}{l}\text { Fallopian tube } \\
\text { abnormalities }\end{array}$} & \multirow{4}{*}{$\begin{array}{l}20 / 93 \\
(21.5 \%)\end{array}$} & \multirow{4}{*}{$\begin{array}{l}14 / 64 \\
(21.8)\end{array}$} & Adherent & $10 / 20(50 \%)$ & $9 / 14(64.3 \%)$ \\
\hline & & & Dilated and tortuous & 8 & 2 \\
\hline & & & Endometriotic patches & 1 & 1 \\
\hline & & & Hidden fimbrial end & 1 & 2 \\
\hline \multirow{6}{*}{$\begin{array}{l}\text { Uterine } \\
\text { abnormalities }\end{array}$} & \multirow{6}{*}{$\begin{array}{l}20 / 93 \\
(21.5 \%)\end{array}$} & \multirow{6}{*}{$10 / 64(15.6 \%)$} & $\begin{array}{l}\text { Bulky uterus } \\
\text { Fibroid / adenomyosis }\end{array}$ & $7 / 20(35 \%)$ & $4 / 10(40 \%)$ \\
\hline & & & Endometriotic patches & 3 & 2 \\
\hline & & & Tubercle & 4 & 0 \\
\hline & & & Adherent and congested & 3 & 2 \\
\hline & & & Hypoplastic uterus & 2 & 0 \\
\hline & & & Acutely retroverted uterus & 1 & 2 \\
\hline \multirow{2}{*}{ Adhesions } & \multirow{2}{*}{$\begin{array}{l}20 / 93 \\
(21.5 \%)\end{array}$} & \multirow{2}{*}{$17 / 64(26.6 \%)$} & Flimsy adhesions & $9 / 20(45 \%)$ & $12 / 17(70.6 \%)$ \\
\hline & & & Dense adhesions & $11 / 20(55 \%)$ & $5 / 17(29.4 \%)$ \\
\hline \multirow{3}{*}{$\begin{array}{l}\text { POD } \\
\text { abnormalities }\end{array}$} & \multirow{3}{*}{$\begin{array}{l}33 / 93 \\
(35.5 \%)\end{array}$} & \multirow{3}{*}{$15 / 64(23.4 \%)$} & Clear fluid & $22 / 33(66.7 \%)$ & $12 / 15(80 \%)$ \\
\hline & & & Hemorrhagic fluid & 8 & 1 \\
\hline & & & Caseous material & 3 & 2 \\
\hline
\end{tabular}

Table 5: Summary of the abnormalities detected in the hysteroscopic examination in primary and secondary infertility patients.

\begin{tabular}{|c|c|c|c|c|c|c|}
\hline $\begin{array}{l}\text { Hysteroscopic } \\
\text { organ } \\
\text { abnormality }\end{array}$ & $\begin{array}{l}\text { Hysteroscopic } \\
\text { abnormalities } \\
\text { in primary } \\
\text { infertility }\end{array}$ & $\begin{array}{l}\text { Sub-categorization } \\
\text { of hysteroscopic } \\
\text { abnormalities in } \\
\text { primary infertility }\end{array}$ & $\begin{array}{l}\text { Patients } \\
\text { number }\end{array}$ & $\begin{array}{l}\text { Hysteroscopic } \\
\text { abnormalities } \\
\text { in secondary } \\
\text { infertility }\end{array}$ & $\begin{array}{l}\text { Sub-categorization } \\
\text { of hysteroscopic } \\
\text { abnormalities in } \\
\text { secondary infertility }\end{array}$ & $\begin{array}{l}\text { Patient } \\
\text { number }\end{array}$ \\
\hline \multirow{9}{*}{$\begin{array}{l}\text { Cervix (external } \\
\text { and internal os), } \\
\text { Uterine cavity } \\
\text { and osteal web } \\
\text { abnormality }\end{array}$} & \multirow{9}{*}{$18 / 93(19.4 \%)$} & $\begin{array}{l}\text { Hypertrophied } \\
\text { endometrium }\end{array}$ & 3 & \multirow{9}{*}{$8 / 64(12.5 \%)$} & $\begin{array}{l}\text { Hypertrophied } \\
\text { endometrium in } \\
\text { Bicornuate uterus } \\
\text { and cervical stenosis }\end{array}$ & 1 \\
\hline & & Uterine septum & 6 & & Uterine septum & 2 \\
\hline & & Cervical stenosis & 2 & & $\begin{array}{l}\text { Uterine polyp/ } \\
\text { fibroid }\end{array}$ & 1 \\
\hline & & Uterine polyp/fibroid & 2 & & $\begin{array}{l}\text { Tubercles/white } \\
\text { patches }\end{array}$ & 1 \\
\hline & & Synechie & 1 & & Tubercles/white & \multirow[b]{2}{*}{1} \\
\hline & & Tubercles & 1 & & $\begin{array}{l}\text { patches and uterine } \\
\text { septum }\end{array}$ & \\
\hline & & Osteal webbing & 1 & & Osteal webbing & 1 \\
\hline & & $\begin{array}{l}\text { Tubercle and osteal } \\
\text { webbing }\end{array}$ & 1 & & \multirow{2}{*}{$\begin{array}{l}\text { Osteal webbing and } \\
\text { uterine septum }\end{array}$} & \multirow[t]{2}{*}{1} \\
\hline & & Vaginal septum & 1 & & & \\
\hline
\end{tabular}

\section{Hysterolaparoscopic interventions}

Out of 157 patients, abnormalities were detected in 125 patients $(\sim 79.6 \%)$ during hysterolaparoscopic examination. Out of these 125 patients, 121 ( 96.8\%) underwent therapeutic interventions in form of ovarian drilling (Figure 1), adhesiolysis, Successful cannulation, fluid drainage, fulguration of white patches, septum resection and chocolate cystectomy. Separately in primary infertile patients, out of 77 patients with abnormal hysterolaparoscopic findings, 73 underwent various therapeutic interventions. While in secondary 
infertility, 48 patients had abnormal hysterolaparoscopic findings and all underwent therapeutic interventions.

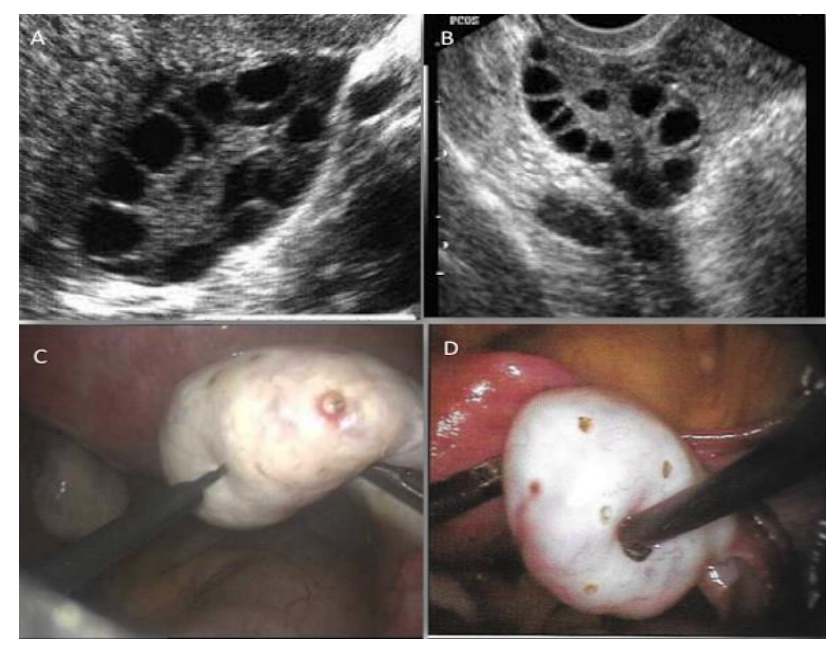

Figure 1: a, b) Bilateral polycystic ovarian disease. c, d) hysterolaparoscopy: variable sized cystic lesions in the both ovaries.

Out of 125,4 patients with abnormal hysterolaparoscopic findings were not underwent active intervention. These patients have streak ovaries and hypoplastic uterus, few small fibroids and adenomyosis in 1, 1 and 2 patients respectively.

In all hysterolaparoscopic patients, during and after the procedure no major surgical and anesthetical complications were reported. Few patients were reported with mild abdominal pain and low-grade fever of short duration.

\section{DISCUSSION}

Hysterolaparoscopy is used for both diagnostic and therapeutic purpose in various abdominopelvic pathologies. In the present study, we assessed the role of hysterolaparoscopy as a theranostic approach in the infertile patients.

According to the literature, detection rate of pelvic abnormalities with the help of hysterolaparoscopy in infertile patients varies from 30-90\%.11 Hysterolaparoscopy mediated pelvic abnormalities were detected in $87 \%$ patients by Jayakrishnan et al, $36 \%$ by Firmal et al and $26-30 \%$ by Nayak et al. ${ }^{11-13}$ In present study, we detected pelvic abnormalities in $\sim 79.6 \%$ female infertile patients.

Of 125 patients with abnormal hysterolaparoscopic findings, we performed the active hysterolaparoscopic intervention in the 121 patients $(\sim 96.8 \%)$. The most common intervention executed in present study was ovarian drilling in 47 patients (isolated or combined with other intervention) comparable to Puri et al. ${ }^{14}$ In present study, through help of hysterolaparoscopy we treated the abdomino pelvic pathologies in $96.8 \%$ patients without damaging other parts of the reproductive system. Only in four patients $(\sim 3.2 \%)$ we could not perform the active intervention due to streak ovaries \& hypoplastic uterus, few tiny fibroids and adenomyosis in 1, 1 and 2 patients respectively. So, it appears hysterolaparoscopy is really a theranostic approach in female infertile patients. To the best of my knowledge, there is no comparable study in the published literature, which provides the exact percentage targeted theranostic approach of hysterolaparoscopy in the infertile female patients.

In all recruited patients, no major surgical and anesthetic complications were reported during and after the procedure. Therefore, hysterolaparoscopy is a safe theranostic approach in the infertile female patients.

The major limitation of present study was that we did not interpret our results in form of pregnancy outcome. The other limitation is, this was a single center study so interoperator variability can lead to discrepancy in outcomes.

\section{CONCLUSION}

Hysterolaparoscopy is a treasured modality for simultaneous diagnosis and treatment of different structural abdomino-pelvic pathologies. Hysterolaparoscopy should be recommended in the initial phases of the work-up in female infertility patients.

\section{Funding: No funding sources}

Conflict of interest: None declared

Ethical approval: The study was approved by the Institutional Ethics Committee

\section{REFERENCES}

1. Collins SC. Precision reproductive medicine: multigene panel testing for infertility risk assessment. J Assist Reprod Genet. 2017;34:967-73.

2. Vegter MW. Towards precision medicine; a new biomedical cosmology. Med Health Care Philos. 2018.

3. Jeelani S, Reddy RC, Maheswaran T, Asokan GS, Dany A, Anand B. Theranostics: A treasured tailor for tomorrow. J Pharm Bioallied Sci 2014; 6:S6-8.

4. Jadvar H. The First Theranostic Conference at the American University of Beirut Medical Center. J Nucl Med. 2018;59:13N.

5. Idée JM, Louguet $\mathrm{S}$, Ballet $\mathrm{S}$, Corot $\mathrm{C}$. Theranostics and contrast-agents for medical imaging: a pharmaceutical company viewpoint. Quant Imaging Med Surg. 2013;3:292-7.

6. Abrao MS, Muzii L, Marana R. Anatomical causes of female infertility and their management. Int $\mathbf{J}$ Gynaecol Obstet. 2013;123 Suppl 2:S18-24.

7. Leena Wadhwa, Pooja Rani, Pushpa Bhatia. Comparative Prospective Study of Hysterosalpingography and Hysteroscopy in Infertile Women. J Hum Reprod Sci. 2017;10:73-8. 
8. Prasanta K Nayak, Purna C Mahapatra, JJ Mallick, S Swain, Subarna Mitra, Jayaprakash Sahoo. Role of diagnostic hystero-laparoscopy in the evaluation of infertility: A retrospective study of 300 patients. J Hum Reprod Sci. 2013;6:32-4.

9. Erhong Zhang, Yanan Zhang, Li Fang, Qingdong Li, Jian $\mathrm{Gu}$. Combined hysterolaparoscopy for the diagnosis of female infertility: a retrospective study of 132 patients in China. Mater Sociomed. 2014;26:156-7.

10. Kabadi YM, Harsha B. Hysterolaparoscopy in the evaluation and management of female infertility. J Obstet Gynaecol India. 2016;66 (Suppl 1):478-81.

11. Firmal P, Yadav R, Agrawal S. A prospective study to evaluate the role of laparohysteroscopy in unexplained infertility. J Obstet Gynaecol. 2015;35:386-8.

12. Jayakrishnan K, Koshy AK, Raju R. Role of laparohysteroscopy in women with normal pelvic imaging and failed ovulation stimulation with intrauterine insemination. J Hum Reprod Sci. 2010;3:20-4

13. Nayak PK, Mahapatra PC, Mallick J, Swain S, Mitra $\mathrm{S}$, Sahoo J. Role of diagnostic hystero-laparoscopy in the evaluation of infertility: A retrospective study of 300 patients. J Hum Reprod Sci. 2013;6:32-4.

14. Puri S, Jain D, Puri S, Kaushal S, Deol SK. Laparohysteroscopy in female infertility: A diagnostic cum therapeutic tool in Indian setting. Int J Appl Basic Med Res. 2015;5:46-8.

Cite this article as: Agrawal N, Yadav P, Fayyaz S, Kaur B. Is hysterolaparoscopy a real theranostic approach for anatomical barriers in female fertility? A future argument. Int J Reprod Contracept Obstet Gynecol 2018;7:2423-8. 